Lepr Rev (1992) 63, 134-140

\title{
Clinical observations on leprosy patients with HIV1-infection in Zambia
}

\author{
ANNA E M VREEBURG \\ Herenstraat 15,2313 AD Leiden, The Netherlands
}

Accepted for publication 31 January 1992

\begin{abstract}
Summary The clinical observations carried out on 10 leprosy patients with HIV1-infection, admitted between 1.1.1986 and 1.5.1988 to the Salvation Army Hospital at Chikankata, Mazabuka, Zambia are described. A total of 8 of this group were newly-diagnosed borderline leprosy patients.

Their clinical data were compared with those of 34 newly-diagnosed borderline leprosy patients, admitted in the same period- $50 \%$ were men, $50 \%$ women.

The clinical presentation, with respect to leprosy, on admission, did not differ very much in both groups. The incidence of neuritis in both groups was $50 \%$ (respectively 5 and 17). The outcome of specific therapy of neuritis was worse in the HIV1 patients than in the other group: only partial recovery in 4 out of 5 and no response in 1 , compared with a complete recovery in 10 cases, and a partial recovery in 7 cases in the other group.

A total of 6 patients of the HIV1-group admitted to have had multiple heterosexual contacts, 5 had a history of sexually transmitted disease, 7 had generalized lymphadenopathy and 4 presented with another disease in addition to leprosy.

While in hospital the group of 10 HIV1-infected patients suffered 17 episodes of intercurrent disease against none in the other group; 1 patient (male) died with generalized dermatitis and sepsis; 1 woman died with fulminant hepatitis.
\end{abstract}

\section{Introduction}

Human immunodeficiency virus type 1 (HIV1) was confirmed in Zambia in $1983 .{ }^{1}$ In this study we report clinical observations on 10 leprosy patients infected with HIV1, admitted to the Leprosy Department of the Salvation Army Hospital, Chikankata, Mazabuka, Zambia between January 1986 and May 1988. This hospital serves as a leprosy referral hospital for the Southern Province of Zambia.

Serological testing for HIV1-antibody was made available for the district hospitals in Zambia at the Microbiology/Pathology Laboratory of the University Teaching Hospital in Lusaka after January 1986. After August 1987 the testing was also done at the medical laboratory of Chikankata Hospital.

Between January 1986 and May 198812 leprosy patients were found to be infected 
with HIV 1; 7 were tested because of clinical suspicion and 5 were found during a survey. ${ }^{2}$ We describe here the 10 available clinical observations - 8 of this group were newlydiagnosed borderline leprosy patients. The findings in this group were compared with those in a group of 34 newly-diagnosed patients with the same classification, admitted in the same period.

\section{Material and Methods}

There were 291 admissions to the Leprosy Department of Chikankata Hospital between January 1986 and May 1988: 82 were newly-diagnosed cases; the remaining 209 were referrals for treatment of complications, leprosy having been diagnosed earlier.

Of the 82 new cases, 68 were newly-diagnosed borderline-leprosy patients (including 8 HIV1 patients). The files of 34 were readily available for analysis.

The findings in the group of 8 patients with HIV1-infection and with newly-diagnosed borderline leprosy were compared with 34 new borderline cases admitted in the same period. From both groups sex, mean age, family history of leprosy, and the time lapsed between the onset of symptoms and reporting for medical attention were compared.

Relevant data concerning their leprosy status and clinical history were compared. The effect of specific therapy was analysed, as were episodes of intercurrent disease other than leprosy reactions.

All the leprosy patients described here were put on multidrug therapy. Those patients found to have active neuritis were treated for the first 2 weeks with $40 \mathrm{mg}$ prednisolone then for 4 weeks with $30 \mathrm{mg}$ prednisolone, and thereafter the prednisolone dosage was reduced by $5 \mathrm{mg}$ every 4 weeks until it was zero. The prednisolone was administered once daily, in the morning. Other drugs, e.g. antibiotics, were prescribed as necessary when indicated.

The serological test used to demonstrate the presence of HIV1-antibodies was the Wellcozyme-anti HTLVIII competitive enzyme-linked immunoassay VK51, the same test as is used in the Microbiology/Pathology Laboratory of the University Training Hospital, Lusaka. All the positive results found at our laboratory were reconfirmed in Lusaka.

\section{Results}

The mean age in the group of 8 patients with newly-diagnosed borderline leprosy and HIV1-infection (group 1) and the group of 34 newly-diagnosed borderline leprosy patients (group 2) did not differ significantly (respectively $42 \cdot 3$ and $41 \cdot 2$ years).

More than $50 \%$ of the patients had a family member who suffered from leprosy. Group 1 patients reported somewhat sooner to the hospital than group 2, respectively within 5 months and 9 months after the start of their symptoms. These differences are because the men in group 2 reported on average 12.8 months after the onset of their symptoms.

In both groups $25 \%$ of the patients had positive skin smears. About $50 \%$ of the patients in both groups reported with active neuritis. In group 2, 10 recovered after specific treatment and 7 improved only partially. The outcome for this complication in 
Table 1.

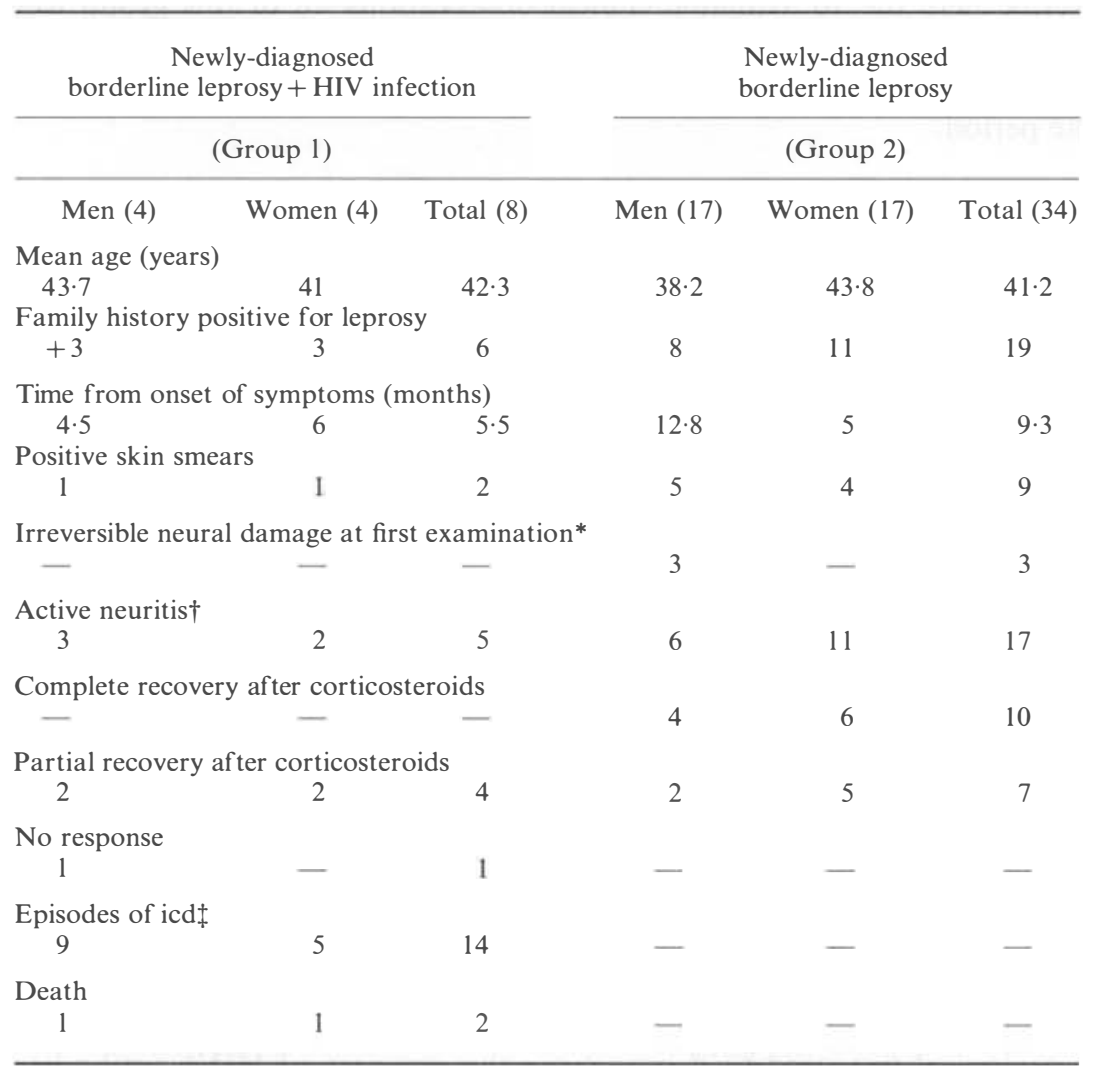

* Irreversible neural damage: neural damage existing longer than 6 months before first examination.

$\dagger$ Active neuritis: signs and symptoms of active neural inflammation, and/or impairment of neural function for a period shorter than 6 months before first examination.

$\ddagger$ Intercurrent disease.

group 1 was much worse: 4 recovered only partially and 1 did not respond at all. Many episodes of intercurrent disease (other than leprosy reactions) were observed in group 1; 2 patients in group 1 died.

The findings are described in more detail in Table 1. Further clinical details in all the group of 10 HIV1-positive were analysed. Table 2 describes their leprosy assessments, classification, specific therapy and treatment outcomes.

Table 3 describes the history of and physical examinations relating to HIV1-infection. None of these patients admitted to drug abuse or to having any homosexual contact. In all, 6 admitted multiple heterosexual contact; 5 had had sexually transmitted diseases (STD) in the past; 7 reported with a generalized lymphadenopathy; 1 with splenomegaly, 1 had hepatomegaly; 2 had active STD on admission; and 4 patients presented themselves with 1 or more afflictions in addition to leprosy.

Table 4 describes the observed episodes of intercurrent disease other than reversal reaction and their outcomes; 17 episodes in 7 patients are noted; 1 male patient (BB, $48 \mathrm{yr}$ ) 
Table 2. Leprosy patients with positive HIV1-serology leprosy assessment

\begin{tabular}{|c|c|c|c|c|c|c|c|}
\hline Sex/age & Presentation & $\begin{array}{l}\text { Duration } \\
\text { symptoms } \\
\text { (m) }\end{array}$ & $\begin{array}{l}\text { Family } \\
\text { leprosy }\end{array}$ & Class & $\begin{array}{c}\text { Skin } \\
\text { smears }\end{array}$ & Therapy & Result \\
\hline $\mathrm{M} / 48$ & Reversal reaction & 5 & + & BB & - & $\mathrm{DT}^{*} / \mathrm{C}^{\dagger}$ & Died \\
\hline $\mathrm{M} / 51$ & Mild E NL. icd $\ddagger$ & 3 & + & LL & + & $\mathrm{TT}^{4} \S$ & Settled \\
\hline $\mathbf{M} / 58$ & Neuritis & 6 & + & BT & - & $\mathrm{DT} / \mathrm{C}$ & Improved \\
\hline $\mathbf{M} / 38$ & Neuritis & 6 & + & $\mathrm{BL}$ & + & $\mathrm{TT} / \mathrm{C}$ & Improved \\
\hline $\mathbf{M} / 31$ & Patches & 1 & $?$ & BT & - & DT & Stable \\
\hline $\mathrm{F} / 29$ & icd & 3 & $\dot{+}$ & $\mathrm{BL}$ & + & TT & Stable \\
\hline $\mathrm{F} / 49$ & Patches mild RR & 2 & $?$ & BT & - & DT & Settled \\
\hline $\mathrm{F} / 35$ & Neuritis & 8 & + & BT & - & $\mathrm{DT} / \mathrm{C}$ & Improved \\
\hline $\mathrm{F} / 30$ & Neuritis & 7 & + & BT & - & $\mathrm{DT} / \mathrm{C}$ & Improved \\
\hline $\mathrm{F} / 50$ & Patches & 7 & $?$ & BB & - & DT & Died \\
\hline
\end{tabular}

* Double therapy:

$600 \mathrm{mg}$ rifampicin once per month supervised.

$100 \mathrm{mg}$ dapsone daily.

$\dagger$ Corticosteroids.

$\ddagger$ icd, intercurrent disease.

$\S$ Triple treatment:

$600 \mathrm{mg}$ rifampicin once per month supervised.

$300 \mathrm{mg}$ clofazimin once per month supervised.

$100 \mathrm{mg}$ dapsone daily.

$100 \mathrm{mg}$ clofazimin three times weekly

$\mathrm{BB}$, borderline leprosy; BT, borderline-tuberculoid leprosy; BL, borderline-lepromatous leprosy; LL, lepromatous leprosy; RR, reversal reaction.

Table 3. History and other clinical findings on admission

\begin{tabular}{|c|c|c|c|c|}
\hline Sex/age & $\begin{array}{l}\text { Multiple } \\
\text { sexual } \\
\text { partners }\end{array}$ & $\begin{array}{c}\text { Sexually } \\
\text { transmitted } \\
\text { disease (STD) }\end{array}$ & Lymphadenopathy & Other \\
\hline $\mathrm{M} / 48$ & Yes & Yes & Yes & - \\
\hline $\mathrm{M} / 51$ & Yes & Yes & Yes & Splenomegaly gonorrhoea \\
\hline $\mathbf{M} / 58$ & Yes & Yes & Yes & - \\
\hline $\mathbf{M} / 38$ & - & Yes & Yes & Chancroid \\
\hline $\mathrm{M} / 31$ & Yes & Yes & Yes & \\
\hline $\mathrm{F} / 29$ & Yes & No & Yes & Bronchitis oral candidiasis \\
\hline $\mathrm{F} / 49$ & No & No & No & - \\
\hline $\mathrm{F} / 35$ & No & No & No & - \\
\hline $\mathrm{F} / 30$ & Yes & No & Yes & Hepatomegaly abscess occiput \\
\hline $\mathrm{F} / 50$ & $?$ & No & No & - \\
\hline
\end{tabular}

died with generalized dermatitis and sepsis; 1 female (BB, 50 yr) died with fulminant hepatitis.

\section{Discusssion}

The group described in this study is very small: studies on larger groups should follow soon. On presentation the group of 8 newly-diagnosed borderline leprosy patients with 
Table 4. Leprosy patients with positive HIVl-serology episodes of intercurrent disease during admission and outcome

\begin{tabular}{lll}
\hline Sex/age & \multicolumn{1}{c}{ Illness } & Outcome \\
\hline M/58 & $\begin{array}{l}\text { Tonsillitis, multiple abscesses, toxic hepatitis, malaria, gener- } \\
\text { alized dermatitis + sepsis } \\
\text { Gonorrhoea, macrocytic anemia (folic acid deficiency), uri- } \\
\text { nary tract infection }\end{array}$ & Died \\
M/58 & None & Recovered \\
M/38 & Chancroid & Recovered \\
M/31 & None & Recovered \\
F/29 & Bronchitis, oral candidiasis & Recovered \\
F/49 & None & Recovered \\
$F / 35$ & Herpes zoster & Died \\
F/30 & Abscess occiput, septic tendovaginitis & \\
F/50 & Pneumonia, fulminant hepatitis & \\
\hline
\end{tabular}

HIV1-infection did not differ very much from the other group of 34 newly-diagnosed borderline leprosy patients in terms of age and presenting signs/symptoms of their leprosy. The only clinical difference was that the group of HIV1-positive patients had poorer outcomes in the treatment of active neuritis.

HIV1 infects neural macrophages, neural multinuclear cells, microglial cells and sometimes neurones. It can also cause peripheral neuropathy. ${ }^{3}$ HIV1 virus readily infects T4 helper cells, which play a key role in cell-mediated immunity. The leprosy bacillus is known to invade macrophages and Schwann cells. ${ }^{4}$ The way the individual handles the leprosy bacillus determines the clinical picture and the outcome of the leprosy infection. ${ }^{5}$ The observations in this group suggest that HIV 1-infection and leprosy infection enhance each other in terms of development of more fulminant neuritis in a relatively short time. More observations, also with histopathological studies, will be required to verify this matter. Otherwise, HIV1-infection in these leprosy patients presented itself as it does in patients without leprosy.

The history and equal distribution among women and men points to the pattern of mainly heterosexual transmission of the disease, as earlier observed in Zambia. ${ }^{6}$ The high incidence of generalized lymphadenopathy (7 out of 10) and the many episodes of intercurrent disease $(16 \times$ infection, $1 \times$ generalized dermatitis $)$ are evidence of compromised immunity. The group is too small to allow conclusions that HIV1-infection tends to be clinically worse than in other HIV1-positive nonleprosy patients, or that the leprosy is more downgraded, even though it is likely that our patients were already having longer established HIV1-infection with advanced immunological disturbance. Observations on more patients in the near future will hopefully clarify this issue.

\section{Conclusions}

HIV1-infection does occur in leprosy patients in Zambia and possibly causes early irreversible neuritis, and HIV1-infection in leprosy patients presents clinically in a similar way to HIV1-infection in nonleprosy patients apart from the observations on neuritis. 


\section{Acknowledgments}

Many thanks to Captain Dr I D Campbell, CMO, for his assistance in many ways. Also I am very grateful to Mr G M Siyunda, Leprosy Control Supervisor and to Captain P J Disney, Laboratory Supervisor and his staff, for the help offered and the good work done in their respective departments.

This work was carried out at the Salvation Army Hospital, Chikankata, Mazabuka, Zambia.

\section{References}

1 Bailey AC, Downing RG, Chingsong-Popov R et al. HTLVIII Serology distinguishes atypical and endemic Kaposi's sarcoma in Africa. Lancet, 1985; 1: 359-361.

2 Meeran KM. Prevalence of H IV-1 infection among patients with leprosy and tuberculosis in rural Zambia. $\mathrm{Br}$ Med J, 1989; 298: 364-5.

${ }^{3}$ Stoler MH, Eskin TA, Penn S, Angerer RC, Angerer Lynne M. Aids and the central nervous system. $J A M A$, 1986; 256: 2360-2364.

4 Issues in World Health: AIDS—a public health crisis. In: Population reports; Series L; 6: p L 198.

5 Browne Stanley G. Pathology, Immunology. In: Browne Stanley G, Leprosy: Basle, Ed. Documenta Geigy, 1984: 39-57.

${ }^{6}$ Melbye M, Nyelesani EK, Bailey A et al. Evidence for heterosexual transmission and clinical manifestations of human immunodeficiency virus and related conditions in Zambia. Lancet, 1986; 2: 1113-1115. 


\title{
Observations cliniques de patients lépreux infectés par HIV1 en Zambie
}

\author{
Anna E M VReEburg
}

Résumé Nous décrivons les observations cliniques de 10 patients lépreux infectés par HIV1, admis à l'Hopital de l'Armée du Salut à Chikankata, Mazabuka, Zambie, entre le 1.1.1986 et le 1.5.1988. Sur ce groupe, 8 au total étaient des cas-limite de lèpre récemment diagnostiqués,

Leurs dossiers cliniques ont été comparés avec ceux de 34 cas-limite de lèpre, récemment diagnostiqués, admis au cours de la même période, $50 \%$ hommes et $50 \%$ femmes.

Le tableau clinique à l'admission, en ce qui concerne la lèpre n'était pas très différent dans les deux groupes. L'incidence des névrites, dans les deux groupes, était de 50\% (respectivement 5 et 17). Le résultat de la thérapeutique spécifique de la névrite était plus mauvais chez les patients HIVl que dans l'autre groupe: seulement 4 guérisons partielles chez 4 de 5 patients traités, et pas de réponse chez 1; en comparaison, l'autre groupe présentait une guérison complète dans 10 cas, et une guérison partielle dans 7 cas.

Six patients au total dans le groupe HIV 1 ont admis avoir eu des contacts hétérosexuels multiples, 5 avaient une histoire de maladie transmise sexuellement, 7 avaient une lymphadénopathie généralisée et 4 avaient une autre maladie en plus de la lèpre.

Pendant leur séjour à l'hopital, les patients du groupe de 10 porteurs de HIVl ont souffert 17 épisodes de maladie intercurrente tandis que l'autre groupe n'en avait aucun; 1 patient est mort de dermatite généralisée et septicémie; une patiente est morte d'hépatite fulminante.

\section{Observaciones clínicas de pacientes leprosos con infección HIV1 en Zambia}

\author{
AnNa E M VReEburg
}

Resumen Se describen las observaciones clínicas ef ectuadas en 10 pacientes leprosos con infección HIV1, recibidos en el Salvation Army Hospital en Chikankata, Mazabuka, Zambia entre el 1.1.1986 y el 1.5.1988. Ocho miembros de este grupo eran pacientes con lepra incierta recién diagnosticada.

Se compararon sus datos clínicos con aquellos de otros 34 pacientes con lepra incierta recién diagnosticada, admitidos durante el mismo período; $50 \%$ de los pacientes eran hombres, $50 \%$, mujeres.

La presentación clínica con respecto a la lepra al ser admitidos no difería muchos entres los dos grupos. La incidencia de neuritis en ambos grupos era 50\% (5 y 17 respectivamente). El resultado de la terapia específica para la neuritis fue peor en el grupo con HIV 1 que en el otro; solamente hubo una recuperación parcial en 4 de 5 casos y ninguna reacción en 2; comparado con una recuperación total en 10 casos, y una parcial en 7, en el otro grupo.

Un total de 6 pacientes del grupo HIV1 admitió contactos heterosexuales múltiples, 5 tenía antecedentes de una enfermedad transmitida sexualmente, 7 tenía linfadenopatía y 4 presentó síntomas de otra enfermedad además de lepra.

Minetras estuvo en el hospital, el grupo de 10 pacientes infectados con HIVl suf rió 17 episodios de enf ermedad intercurrente comparado con ninguno en el otro grupo; 1 paciente (varón) murió con dermatitis generalizada y sepsis; 1 mujer murió con hepatitis fulminante. 